\title{
“Tıp terimleri” üzerine yapılan çalışmalar hakkında bir bibliyografya denemesi
}

\section{Sibel MURAD 1}

\begin{abstract}
APA: Murad, S. (2019). "Tıp terimleri” üzerine yapılan çalışmalar hakkında bir bibliyografya denemesi. RumeliDE Dil ve Edebiyat Araşturmaları Dergisi, (14), 55-67. DOI: 10.29000/rumelide.540994
\end{abstract}

\section{$\ddot{O} \mathbf{z}$}

Türk dilinin terim yaratmadaki gücünü gösterdiği eserler arasında şüphesiz bilim tarihi eserleri önemli bir yere sahiptir. Birçok farklı bilim dalında telif ve tercüme eser veren Türk dilinin, terim üretmedeki çeşitliliğini izleyebildiğimiz bilim eserlerinden biri de tıp konulu metinleridir. Müstakil olarak tıp konusunu ele alan eserler yanında, içeriğinde tıp terimleri bulunan, farklı konularda yazılmış birçok eser bulunmaktadır. Günümüze kadar tıp metinleri, tıp sözlükleri ve tıp terimleri üzerine birçok çalışma yapılmış olup, halen tıp metinleri, tıp sözlükleri ve tıp terimleriyle ilgili çalışmalar yapılmaya devam etmektedir. Bugüne kadar yapılmış çalışmaların bir kısmı doğrudan tıpla ilgili olmayan eserlerdeki tıp terimleri üzerineyken, bir kısmı da doğrudan tıp konulu eserlerdeki terimlerle ilgilidir. Tıp terimleri kavramının içine dâhil edilen ilaç, tıpta kullanılan bitkiler, hayvansal-madensel maddeler, insan ve hayvan organları; hastalıklar, tedavi yöntemleri, tıbbi aletler gibi birçok terimle ilgili çalışmalar yapılmıştır. Çalışmalar "tıp terimli” başlıklı olanlar, tıp terimlerinden herhangi birini konu edinenler ve terimler için önemli bir kaynak olan sözlükler üzerinde yoğunlaşmıştır. Bu çalışmada günümüze kadar tıp terimleri üzerine yapılan çalışmalar ortaya konacak, bunlardan bazıları özetlenerek açıklanacaktır. Böylece tarihi tıp metinleriyle ve tıp terminolojisiyle ilgilenen bilim insanlarına bu alanda yapılan çalışmalar hakkında bilgi verilecek, hangi konuların ele alındığı ortaya konarak henüz üzerinde çalışılma yapılmayan konular hakkında araştırmacılara fikir sağlanacaktır.

Anahtar kelimeler: Tıp terimleri, bibliyografya, tıp metinleri, tıp sözlükleri.

\section{Studies on medical terms: A bibliyographic study}

\begin{abstract}
Undoubtedly, historical works of science have an important place among the works in which the Turkish language demonstrates its power in creating terms. One of the scientific works in which we can observe the diversity of the Turkish language in terms of production in terms of orijinal and translation in many different disciplines is the medical texts. Apart from only the works dealing with the subject of medicine, there are many works written on different topics in terms of medical terms. To date, many studies have been done on medical texts, medical dictionaries and medical terms, and still work on medical texts, medical dictionaries and medical terms. While some of the studies conducted so far are directly related to the medical terms in non-medical works, some are directly related to the terms in the books on medicine. There are studies about the drug included in the
\end{abstract}

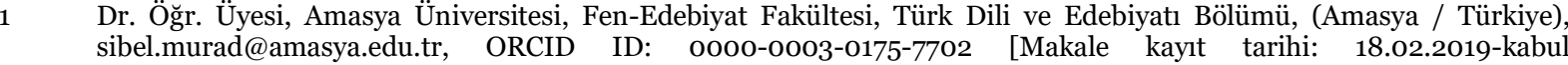
sibel.murad@amasya.edu.tr, ORCID ID: O000-0 


\begin{abstract}
concept of medical terms, plants used in medicine, animal-mineral substances, human and animal organs; diseases, treatment methods, medical instruments. Studies are generally about general medical terms, any of the medical terms and dictionaries. In this study, studies on medical terms will be revealed and some of them will be summarized. In this way, those working in this field will be informed about historical medical texts and medical terminology and to the researchers will give an idea about the subjects not yet studied.
\end{abstract}

Key words: Medical terms, bibliography, medical texts, medical dictionaries.

\title{
Giriş
}

Türkçenin Anadolu'da ilk olarak tercümelerle başlayan bilim dili haline gelme süreci, telif eserlerin verilmesiyle devam etmiştir. Birçok alanda meydana getirilen eserlerde, Türk dilinin terim üretme gücü kendini göstermiştir. Hayatın devamlılığının olmazsa olmazı olan sağlık, merkezinde insan olması hasebiyle, her toplumda olduğu gibi Türk toplumu için de öncelikli konulardan biri olmuştur. Türkçe yazılan tıp konulu eserlere ilk olarak Uygur döneminde rastlanmıştır. Daha sonraki dönemlerde doğrudan tıpla alakalı olmasa da Divânü Lügati’t-Türk ve Kutadgu Bilig gibi eserlerde tıp-sağllk terimlerine rastlanmaktadır. Anadolu sahasında tıpla ilgili bilinen Türkçe ilk tercüme eser, Hekim Bereket'in yazılış tarihi bilinmeyen Tuhfe-i Mübârizî̉ adlı eseri olup tarihi bilinen ilk tercümemiz ise 14 . yüzyılda yapılan Müfredât-ı İbni Baytar Tercümesi'dir. Tarihi bilinen Türkçe ilk telif tıp eseri ise İshak bin Murad'ın Edviye-i Müfrede3 (14.yy.) adlı eseridir. Gerek bunlar gerekse bunlardan sonraki tercüme ve telif tıp konulu eserler üzerine birçok araştırmacı çalışmalar yaparak eserleri günümüze kazandırmışlardır. Yine konu hakkında lisansüstü tezler yapılmış, çok sayıda kitap ve makale yayımlanmıştır.

Tip eserleri üzerindeki çalışmaların birçoğu tarihî bir tıp yazmasının tanıtılıp dil bakımından incelemesinden meydana gelen kitap ve lisansüstü çalışmalardır. Bunların yanı sıra doğrudan veya dolaylı olarak tıpla ilgili bir metin üzerinde yapılan tıp-sağlık terimleriyle ilgili çalışmalar da mevcuttur.

Çalışmamız, günümüze kadar yapılan "tıp terimleri” ile ilgili çalışmalarla sınırlı tutulmuş, bir tıp eserinin kapsamlı olarak (metin-inceleme-dizin) ele alındığı kitap ve lisansüstü çalışmalar bibliyografyaya dâhil edilmemiştir.

Bibliyografyanın herhangi bir bilimsel konuda araştırıcılara ışı tutan önemli bir rehber olduğu ve araştırmacıların araştırdıkları konu hakkında daha önce yapılan çalışmalardan haberdar olmalarının bir gereklilik olduğu düşünülerek çalışmamızın tıp-sağlık terimleri üzerine çalışma yapacak bilim insanlarına faydalı olması amaçlanmıştır.

Hazırladığımız bibliyografya denemesinde tıp-sağlık terimleri genel başlı̆̆ı altında hastalık, ilaç, tıbbi alet, tıpta kullanılan bitki, hayvansal-madensel madde adlarıyla ilgili yapılan çalışmalar ve tıp terimlerini konu alan sözlük çalışmaları ele alınacaktır.

\section{Tıp-sağlık terimleri}

Tıp biliminin malum olduğu üzere özel bir terminolojisi vardır. Tıp biliminin Antik Yunan ve Doğu'dan çıktığı düşünülürse tıp terminolojisinde kullanılan sözcüklerin kökenleri de tahmin edilebilir. Tarihî tıp 
eserlerinde karşılaşılan birçok terim ve özellikle tıpta kullanılan birçok bitki adı Grek, Hint, Arap dillerine aittir.

Telif, tercüme ve tercümelere zaman zaman yapılan bazı ilavelerle yazılan tıp konulu eserler üzerinde çok sayıda terimsel çalışmalar yapılmıştır. Bu konuda yapılmış tespit edebildiğimiz 57 adet çalışma bulunmaktadır. Bu çalışmaların 47'si makale, 5’i bildiri, 5’i de lisansüstü tezlerden oluşmaktadır.

\section{Tıp-sağlık terimleri üzerine yapılan genel çalışmalar}

Tıp terimleri başlıklı genel çalışmalardan bazıları Türk dilinin tarihî dönemlerine ait eserler üzerinde yapılan tıp-sağlık terimlerini inceleyen çalışmalardır. Bunlardan ikisi Macidegül Batmaz tarafindan yapılan "Eski Uygur Türkçesinde Tıp Terimleri” adlı yüksek lisans tezi ve "Eski Anadolu Türkçesi Tıp Terimleri” adında Seyfullah Türkmen tarafından yapılan doktora tez çalışması olup diğerleri çoğunlukla Divânü Lügatït-Türk ve Kutadgu Bilig'deki tıp-sağllk terimlerini tespit eden çalışmalardan oluşmaktadır.

Macidegül Batmaz, yüksek lisans çalışmasında Uygurca tıp terimlerini yapı, köken ve konuları bakımından incelemiş ve çalışmasının sonuna bir terimler dizini ilave etmiştir. Çalışmasını yapılarına, kökenlerine ve konularına göre Uygurca tıp terimleri olarak üç başlık altında toplamıştır. Terimlerin incelenmesinde art zamanlı karşılaştırma yapılmış, yer yer de çă̆daş Türk şivelerinden örnekler verilmiştir. Uygurcanın tıp terimleri bakımından durumunu ve terim yapma zenginliğini gösteren bir çalışmadır.

Tıp terimleriyle ilgili başka bir tarihî şive çalışması olan "Eski Anadolu Türkçesi Tıp Terimleri” adlı doktora çalışması da tıp eserlerinin tercüme ve telif olarak verilmeye başladığı döneme ait önemli bir çalışmadır. Eski Anadolu Türkçesiyle yazılmış tıp eserlerini inceleyen Seyfullah Türkmen, çalışmasını vücudun organ, bölge ve salgıladığı madde adları, hastalık adları ve hastalıkla ilgili terimler, ilâç adları, tıp aletleri, tıpta kullanılan gereçler, tıpla uğraşanlara verilen adlar, tedavi etme ve sağlıkla ilgili terimler, tıpla ilgili genel kelimeler olarak sekiz alt başlık altında toplamıştır. Çalışmasının sonuna Türkçe, Arapça, Farsça, Yunanca terimler dizini eklemiştir.

Tıbbi terimler üzerine yapılan çalışmalar farklı dönemlere ait eserlerde de incelenmiştir. Bu çalışmaların bir kısmı doğrudan tıp konulu eserler olmayıp belli bir eser üzerinde tıbbi terimleri inceleyen çalışmalardır. İslamiyet’in kabulünden sonra Karahanlı Türkçesiyle verilen ilk eserlerimiz üzerinde tıpsağlık terimleriyle ilgili çok sayıda çalışma yapılmıştır. Bunlardan biri Ali Haydar Bayat'ın "Dîvânü Lûgati't-Türk'te Tıbbî Terminoloji” adlı çalışmasıdır. Divânü Lügâti’t-Türk’teki tıbbi terminolojiyi; anatomi, belirtiler-hastalıklar, tedaviler-ilaçlar, tıbbi aletler başlıkları altında incelemiş ve Dîvânü Lûgati't-Türk'ün tıpla ilgili tüm sözcüklerini ortaya koymuştur. Bu dönem eserleriyle ilgili diğer bir çalışma da Zafer Önler’in "Divânü Lügâtit-Türk ve Kutadgu Bilig'de Tıp Terimleri” adlı makalesidir. Dîvânü Lûgati't-Türk ve Kutadgu Bilig'deki tıp-sağlık terimlerinin dolaylı olarak geçtiğini ve bu terimlerin sayıca fazla olmadıklarını ifade eden Önler, bu iki eserde tespit ettiği 22 Türkçe tıp terimini açılayarak kökenleri hakkında bilgi vermiştir. Arapça-Farsça olan altı terimin anlamlarını ve geçtikleri yerleri göstermiştir.

Zafer Önler’in bir başka çalışması da "Eski Anadolu Türkçesi Döneminde Yazılmış İki Tıp Kitabında Yer Alan Sağlık Bilgisi Terimleri” makalesidir. Bu makale de Müntahab-ı Şifa ve Hazâinü's- Saadât adlı iki eserde bulunan tıp-sağlık terimlerini kapsayan bir sözlük çalışmasıdır. 
Kazım Köktekin’in de Hazâinü’s-Saadât’taki tıp terimleri üzerine bir çalışması bulunmaktadır.

“Eski Anadolu Türkçesi Eserlerinden Tertib-i Muâlece'deki Organ Adlı Tıp Terimleri” çalışmasında organ adlarından oluşan tıp terimlerini köken ve yapı bakımından sınıflandıran Gürkan Gümüşatam, eserde alet/araç adlarının çok olmadığını tespit ettiğini ifade etmiştir.

Yukarıda bahsettiğimiz çalışmalarla birlikte "tıp terimleri” başlıklı çalışmalar şunlardır:

1. Adıgüzel, A. (2016). Râhatu'n-nüfus'ta Cinsel Sağlık İle İlgili Terimler. Turkish Studies International Periodical For the Languages, Literature and History of Turkish or Turkic, 11(4), 19-66.

2. Altıntaş, A. (1985). Divan-ı Lügat-it-Türk’teki Tıb Terimleri. Erciyes Üniversitesi Trp Fakütesi Dergisi, 7(1), 3-17.

3. Batmaz, M. (2013). Eski Uygur Türkçesinde Tip Terimleri. (Yayımlanmamış yüksek lisans tezi). Hacettepe Üniversitesi/Sosyal Bilimler Enstitüsü, Ankara.

4. Bayat, A. H. (2003). Dîvânü Lûgati't-Türk'te Tıbbî Terminoloji. Yeni Trp Tarihi Araştırmaları, 9, $103-122$.

5. Bayat, A. H. (2008). Tip Dili ve Terimleri Açısından Eski Anadolu Türkçesiyle Yazılmış Tıp Kitaplarının Önemi. Yeni Tip Tarihi Araştırmaları, 10/11, 61-82.

6. Çelik, A. (2016). XIV.- XV. Yüzyıl Eski Anadolu Türkçesi Tıp Metinlerinde Yer Alan Farsça ve Grekçe Menşeli Terimlerin Yazımındaki Tutarsızlıklara Bazı Örnekler. Uluslararası Sosyal Araştırmalar Dergisi, 9(46), 65-70.

7. Doğan, A. T. (2015). Kitab-ı Tıbb-ı Hikmet'te Geçen Yabancı Tıp Terimlerine Türkçe Karşılıklar. Turkish Studies International Periodical For the Languages, Literature and History of Turkish or Turkic, 10(8), 903-918.

8. Doğan, A. T. (2017). Türklerin Dünyasından Uzaklaşan Türkçe Tıp Terimleri: Eski Anadolu Türkçesinden Türkiye Türkçesine. I. Uluslararası Türklerin Dünyası Sosyal Bilimler Sempozyumu,1114 Mayıs, Antalya.

9. Gözlü, E. K. (2012). "Betimleyici Tıp Terimi” Kavramı ve Eski Anadolu Türkçesiyle Yazılmış Tıp Metinlerindeki Betimleyici Terimler. TÜBAR, 31, 169-179.

10. Gümüşatam, G. (2009). Eski Anadolu Türkçesi Eserlerinden Tertib-i Muālece'deki Organ Adlı Tıp Terimleri. Türk Dili Araştırmaları Yillı̆̆ Belleten, 1, 25-49.

11. Gümüşatam, G. (2010). Eski Anadolu Türkçesinde Eczacılık Terimleri ve Bu Terimlerin Tıp, Botanik, Zooloji, Madencilik, Kimya Terimleriyle İlişkileri. Turkish Studies International Periodical For the Languages, Literature and History of Turkish or Turkic, 5(2), 1033-1087.

12. Günyüz, M. (2005). Şair ve Hekim Ahmedî’nin Duygu Dünyasında Tip Terimleri. 38. Uluslararası Tip Tarihi Kongresi Bildiri Kitabı, 2, 651-670 (1- 6 Eylül 2002). 
13. Gürlek, M. (2014). Cerrahiyetü'l-Haniye'de Geçen Türkçe Tıp Terimleri. Milli Türkoloji Sempozyumu, 440-452, İstanbul.

14. Gürlek, M. (2016). Yabancı Tıp Terimlerine Osmanlı Tıp Metinlerinden Türkçe Karşıllk Örnekleri. Abant İzzet Baysal Üniversitesi Sosyal Bilimler Enstitüsü Dergisi, 16(4), 215-236.

15. Köktekin, K. (2007). Hazâinü's-Saadât’ta Geçen Tıp Terimleri. A. Ü. Türkiyat Araştırmalar Enstitüsü Dergisi, 35, 13-27.

16. Önler, Z. (1989). Eski Anadolu Türkçesi Döneminde Yazılmış İki Tıp Kitabında Yer Alan Sağlık Bilgisi Terimleri. Türk Dili Araştırmaları Yllhı̆ı-Belleten, 89-130.

17. Onler, Z. (1998). XIV-XV. Yüzyıl Türkçe Tıp Metinlerinin Dili ve Söz Varlığı. Kebikeç, 6, 157-168.

18. Önler, Z. (2006). Divânü Lügâtit-Türk Ve Kutadgu Bilig'de Tıp Terimleri. Kebikeç, 22, 135-150.

19. Şehsuvaroğlu, B. N. (1960). Anadolu'da Türkçeleşme Cereyanları ve Türkçe İlk Tıp Yazmalarındaki Terimler. Sekizinci Türk Dil Kurultayında Okunan Bilimsel Bildiriler, Ankara.

20. Tokat, F. (2012). Karakalpak Türkçesindeki Tıp Terimleri. Pamukkale Üniversitesi Sosyal Bilimler Enstitüsü Dergisi, S.13, s. 1-15.

21. Türkmen, Seyfullah (2006). Eski Anadolu Türkçesi Tip Terimleri. (Yayımlanmamış doktora tezi). Kırıkkale Üniversitesi/Sosyal Bilimler Enstitüsü, Kırıkkale

\section{Belirli tıbbi terimler üzerine yapılan çalışmalar}

Yukarıda bahsettiğimiz çalışmalar, daha çok tıp terimlerinin tamamını ele alan çalışmalardır. Bu genel çalışmaların yanında tıp terimlerinden bazılarını konu alan birçok çalışma da mevcuttur. Bu çalışmalar tıpta kullanılan ilaçlar, aletler, ilaç yapımında kullanılan bitkiler, hayvansal maddeler, hayvan ve insan organları ve hastalık adları üzerinedir.

Mahmut Gürgan’a ait olan “İslam Öncesi Dönem Uygur Tıp Metinlerinde Bulunan Hayvansal Drog İsimleri” adlı çalışmada Uygur dönemine ait tıp metinleri incelenmiş ve bu inceleme sonucunda 19 hayvansal drog maddesi başlı̆ı̆ında toplam 47 terim açıklanmıştır. Geleneksel Hint tıbbından etkilenen Uygur tıbbında, Hint tıbbının aksine hayvansal droglara sıç̧a rastlandığını (özellikle kurt dili, kurt kemiği, kurt ödü gibi) belirten Gürgan, eski Uygur hekimlerinin başka dillerden çevrilen tıp metinleriyle yetinmeyerek kendi deney ve yöntemlerini de kullanarak bir tıp anlayışı geliştirdiklerini ifade etmiştir.

Bir tıp teriminin etimolojisi hakkında yazılan Galip Güner'in "Dîvânü Lugâti'tTürk’te Oğuzca Olarak Geçen Mandār ve Mandārlan- Kelimelerinin Kökeni Üzerine Düşünceler” adlı makalesinde Dîvânü Lugâti’t-Türk'te geçen "mandār" adlı ağaçlara sarılan ve çoğunlukla ağaçları kurutan bitki adının kökeni ve aynı kökten türediği düşünülen "mandârlan- (ağaç sarmaşıkla kaplanmak, sarmaşıllanmak)” sözcüklerinin kökenleri üzerine görüşler sunulmuştur.

Divanü Lügatït-Türk'le ilgili bu alanda yapılan bir diğer çalışma da Canan İleri’ye aittir. İleri, "Divanü Lügati't-Türk’te Geçen Meyve ve Sebze Adları ve Türklerin Bunlardan Yararlanma Biçimleri” başlıklı makalesinde meyve sebze adlarını kullanım alanlarına göre beslenme, sağaltma ve araç-gereç 
yapımında olmak üzere üç ana başlık altında toplamıştır. İleri, Divanü Lügati’t-Türk’te sağaltmada kullanılan tıbbi bitkileri, “Tarama Sözlüğü” ve Turhan Baytop’un “Türkiye'de Bitkilerle Tedavi; Geçmişte ve Bugün” (1984) ile karşılaştırarak kullanımları bakımından insan sağaltmada ve hayvan sağaltmada kullanılan meyve-sebzeler olarak ikiye ayırmıştır.

Yine Divanü Lügati’t-Türk'te, göz ve göz hastalıklarıyla ilgili sözcükleri konu alan bir çalışması bulunan Berdi Sarıyev, bunların yanında hastalık isimleri, tedavide kullanılan bitkiler ve ilaçları incelemiş ve bazı sözcüklerin Türkmen Türkçesindeki karşılıklarına da yer vermiştir.

Özetlediğimiz çalışmalarla birlikte diğer çalışmalar aşağıda verilmiştir:

1. Altıntaş, A. (2001). Divanu Lüğat-it Türk'teki Tıbbi Bitkiler. Tip Tarihi Araştırmaları, 10, 64-71.

2. Bailey, H. W. (1953). Medicinal plant names in Uighur Turkish. Melanges Fuad Köprülü/ Fuad Köprülü Armağanı. Ankara: Ankara Üniversitesi Dil ve Tarih Coğrafya Fakültesi Yayını, 51-56.

3. Güner, G. (2014). Dîvânü Lugâti’t-Türk’te Oğuzca Olarak Geçen mandār ve mandārlanKelimelerinin Kökeni Üzerine Düşünceler. Teke, 3(2), 54-61.

4. Gürgan, M. (2013). İslam Öncesi Dönem Uygur Tıp Metinlerinde Bulunan Hayvansal Drog İsimleri. Avrasya Terim Dergisi, 1 (2), 88- 94.

5. İleri, C. (2007). Divanü Lügati’t-Türk'te Geçen Meyve ve Sebze Adları ve Türklerin Bunlardan Yararlanma Biçimleri. Türk Dili, 669, 542-572.

6. Sarıyev, B. (2008). Divan'da Göz ve Göz Hastalıklarıyla İlgili Sözcükler Üzerine Bir İnceleme. Modern Türklük Araştırmaları Dergisi, 5(4), 13-23.

Tıp dilinin Anadolu'da oluşmaya başladığı dönem olan Eski Anadolu Türkçesi yukarıda da belirttiğimiz gibi pek çok tercüme ve telif eserin ortaya çıktığı bir dönemdir. Eski Anadolu Türkçesinin devamında oluşan Osmanlı Türkçesi döneminde de telif/tercüme birçok tıp eseri bulunmaktadır. Her iki döneme ait konuyla ilgili eserler üzerinde ilaç, bitki, hastalık, tıbbi alet konusunda bazı çalışmalar yapılmıştır.

Bitki adlarıyla ilgili yapılan çalışmalar aşağıda da açıkladığımız tıptan çok botanik alanıyla ilgilidir. Ancak bu bölümde ele alacağımız çalışmaların tıpla doğrudan ilgili eserlerde kullanılan bitki adları üzerine olduğunu belirtmek gerekmektedir.

Zafer Önler tarafından kaleme alınan "Hacı Paşa'nın Müntehâb-ı Şifâ Adlı Eserinde Geçen Bitki Adları Üzerine" adlı makalede, 14. yüzyılın sonlarında yazılan Müntehâb-ı Şifâ (Önler, 1990) adlı eserdeki, kökenleri bakımından Türkçe, Arapça, Farsça, Yunanca olan bitki adlarından bazılarının Arapça, Farsça ve Türkçe karşılıklarının semantik açısından benzerlik gösterdiği örneklerle açıklanmıştır.

Yine Önler'e ait olan "XIV. ve XV. Yüzyll Anadolu Türkçesi Botanik Terimleri (Edviye-i Müfrede, Hazâinü’s-Saâdât, Mücerrebnâme, Yâdigâr-ı İbn-i Şerîf)" ve "14.-15. Yüzyll Tıp Metinlerinde Bitki Adları" gibi çalışmalar da bulunmaktadır. 
Paki Küçüker, çok dilli bir ecza sözlüğü olarak 17. yüzyılda hazırlanan Lügat-i Müşkilât-ı Eczâ’da (Murad, 2009) yer alan Türkçe bitki adları üzerine çalışmasında eserdeki dört yüz on yedi bitki adından bahsetmiştir.

Gürkan Gümüşatam'a ait “Risâle-i Mu'âlece'ye Göre XVI. Yüzyll Türkçesinde Tıbbi Bitki Adları” adlı çalışmada, tedavi üzerine yazılan bir risale olan Risâle-i Mu'âcele'de yer alan Türkçe bitki adlarını tek kelimeden oluşan bitki adları, belirtisiz isim tamlaması ve sıfat tamlaması kuruluşunda bitki adları olarak üç alt başlıkta yapılarına göre incelemiştir. Daha sonra eserdeki diğer bitki adlarını Arapça, Farsça, Grekçe olarak sınıflandırmıştır.

“Osmanlı Tıp Metinlerinde Geçen Hastalık Adları Üzerine” adlı makalelerinde 14-18. yüzyllar arasındaki 21 tıp metninde 284 tıp terimi tespit eden Mehmet Gürlek ve Ahmet N. Çiçekler, Türkçe dışında 90 Arapça, 8 Farsça, 3'er terim ile Yunanca ve Fransızcanın hastalık adlarında etkisinin görüldüğünü tespit ettiklerini belirtmişlerdir.

Yukarıda kısaca bahsettiğimiz çalışmalarla birlikte bu başlık altında yapılmış çalışmalar şunlardır:

1. Bayat, A. H. (1992). Anadolu Tıbbi Folklorunda Göz Hastalıkları. IV. Milletlerarası Türk Halk Kültürü Kongresi Bildirileri, C. IV, s. 43-58. Ankara: Kültür Bakanlığı Halk Kültürlerini Araştırma ve Geliştirme Genel Müdürlüğü Yayınları.

2. Demir, E. (2012). Hezârfen Hüseyin b. Ca’fer İstânköyînnin Fihrîsü’l-Ervâm Adlı Eserinde Geçen Bitki Adları. TDED, 46, 1-28.

3. Gümüşatam, G. (2015). Risâle-i Mu'âlece'ye Göre XVI. Yüzyıl Türkçesinde Tibbi Bitki Adları. Jass, 39(3), 23-40.

4. Gürlek, Mehmet (2011). 'Alâ’im-i Cerrâhîn'de Geçen Bitki Adları. Adıyaman Üniversitesi Sosyal Bilimler Enstitüsü Dergisi, 7, 123-145.

5. Gürlek, M., Çiçekler, A. N. (2016). Osmanlı Tıp Metinlerinde Geçen Hastalık Adları Üzerine. Turkish Studies International Periodical For the Languages, Literature and History of Turkish or Turkic, 11, 95-112.

6. Gürlek, M. (2015). Osmanlı Tıp Metinlerinde Geçen Cerrahî Alet Adları Üzerine. Firat Üniversitesi Sosyal Bilimler Dergisi, 25(1), 39-49.

7. Küçüker, P. (2010). Lügat-i Müşkilât-ı Eczâ’da Türkçe Bitki Adları. Uluslararası Sosyal Araştırmalar Dergisi, 3(11), 401-415.

8. Küçüker, P., Yıldız, Y. (2016). Tercüme-i Müfredât-ı İbn-i Baytar'daki (1b-150a) Bitki Adları Üzerine Bir İnceleme. Jass, 44, 13-32.

9. Küçüker, P., Yıldız, Y. (2018). Tercüme-i Müfredât-ı İbn-i Baytar'daki (15ob-295a) Bitki Adları Üzerine Bir İnceleme II. Uluslararası Türk Lehçeleri Araştırma Dergisi (TURKLAD),2/1, 109-137.

10. Murad, S. (2011). Terceme-i Akrabâdîn'de Terkipler ve Adlandırmaları. Osmanlı Bilimi Araştırmaları, Eczacılık Tarihi II, Eğitim, Araştırma ve Metinler, 12, 81-94. 
11. Önler, Z. (1986). Hacı Paşa'nın Müntehâb-ı Şifâ Adlı Eserinde Geçen Bitki Adları Üzerine. Türk Dili Dil ve Edebiyat Dergisi, 51(413), 403-406.

12. Önler, Z. (1990). XIV. ve XV. Yüzyll Anadolu Türkçesi Botanik Terimleri (Edviye-i Müfrede, Hazâinü's-Saâdât, Mücerrebnâme, Yâdigâr-ı İbn-i Şerîf). Journal of Turkish Studies, (Fahir İz Aramağamı I), 14, 357-392.

13. Önler, Z. (2004). 14.-15. Yüzyl Tıp Metinlerinde Bitki Adları. Kebikeç, 18, 273-302.

14. Yaylagül, Ö. (2014). Eski Uygur Türkçesi ve Batı Orta Türkçesiyle Yazılmış Tıp Metinlerindeki Fiiller. Bilig, 68(2), 267-296.

Bu çalışmalar dışında, tarihi şivelerimize ait Divanü Lügati’t-Türk, Kutadgu Bilig, Codex Cumanicus vb. gibi birçok eser üzerinde içerdikleri bitki, hayvan ve organ adlarıyla ilgili çalışmalar yapılmıştır. Bunlar içinde özellikle bitki adlarıyla ilgili yapılan çalışmalar öne çıkmaktadır. Bitkiler hakkında yapılan çalışmaların fazla olması, bitkilerin tıbbi özelliklerinin zirâi özelliklerinden fazla olmasına bağlanabilir. Ancak yapılan bazı çalışmalarda her zaman bir bitkinin tıp alanındaki kullanımlarına değinilmemiştir. Bitki gibi tıpla ilgili bir terim olarak da karşılaşılan hayvan, organ adlarıyla ilgili yapılan çalışmaların hepsi her zaman doğrudan tıpla ilgili değildir; ancak bunların tıpta da kullanılmaları sebebiyle bu çalışmalara örnek vermek yerinde olacaktır:

1. Aydın, E. (2016). Eski Türk Yazıtlarında Bitkiler ve Hayvanlar. Türk Kültürü Araştırmaları Dergisi, 9(1), 1-51.

2. Çakmak, C. (2015). Dîvânu Lugâti't-Türk'te Vücut ve Organ Adları. Uluslararası Sosyal Araştırmalar Dergisi, 8(41), 135-143.

3. Hauenschild, I. (1998). Botanica im Dīwān lugāt at-turk. Journal of Turkology, 2(1), 25-100.

4. Hauenschild, I. (2006). Botanica und Zoologica im Babur-name. Einelexikologische und kulturhistorische Untersuchung Wiesbaden: Harrassowitz.

5. Karadeniz, Y. (2017). Codex Cumanıcus'ta Bitki Adları. Celal Bayar Üniversitesi Sosyal Bilimler Dergisi, Vol. 15 Issue 1, s.611-638.

6. Nyiri, M. (1985). Kaşgarlı Mahmud'un Divanü Lügati’t Türk Adlı Sözlüğündeki Bitki Adları. Beşinci Milletler Arası Türkoloji Kongresi Tebliğleri, 205-213.

7. Öztürk, F. (2005). Kutadgu Bilig'de Bitki Adları. Türk Dünyası İncelemeleri Dergisi, 6(1), 201-208.

8. Usmanova, M. S. (2013). Ali Şir Nevai Eserlerinde Bitki Adları. Dil ve Edebiyat Araştırmaları, 8, 117143 .

\section{Tek bir terim üzerine yapılan çalışmalar}

Buraya kadar özetlediklerimiz dışında sadece bir tıbbi terim üzerinde duran çalışmalara da rastlanmaktadır. Bunlardan bazıları bir tıp teriminin farklı adlandırmalarını konu edinirken bazıları ise 
bir tıp teriminin kökeni hakkında görüşler sunmaktadır. Bu çalışmalar da ağırlıklı olarak bitki adları üzerine yapılmıştır.

Erhan Aydın’ın "Eski Türk Yazıtlarında Bitkiler ve Hayvanlar" çalışmasında da yer verdiği "çıntan ıgaçsandal ağacı" üzerine müstakil bir çalışması daha bulunmaktadır. Bu çalışmada Aydın, "çıntan" sözcügünün kökeni hakkındaki görüşlere yer vererek bu ağacın Uygur metinleri dışında sadece Bilge Kağan yazıtı Güney 11. satırda geçtiğini söylemiştir. Devamında "çıntan ıgaç-sandal ağacı" hakkında bilgiler vererek bitkinin tıp ve diğer birçok alanda kullanımlarından bahsetmiştir.

"Eski Anadolu Türkçesiyle Yazılmış Tıp Metinlerindeki İki Terim Üzerine Tespitler: Çignemek ve Çeynemek" adlı Emel Kaya Gözlü tarafından kaleme alınan makalede "çignemek ve çeynemek" fiillerinin iki farklı sözcük oldukları halde Eski Anadolu Türkçesiyle yazılmış tıp eserlerinin Türkiye Türkçesine çevirilerinde karıştırıldıklarına ve yanlış anlamlandırıldıklarına değinmiştir. "çignemek” sözcüğünün "vücut kırıklığı, kırgınlık”, “çegnemek”in ise bir ilacı yutmak, ağızda ezmek vb. gibi anlamları olduğunu açıklamıştır.

Bu çalışmalarla birlikte benzeri çalışmalar şunlardır:

1. Atnur, G. (2011). Osmanlı Tıp Yazmaları ile Halk Hekimliğinde "Hafakan (Afakan)" ve Hazâ 'ìlâc-ı Hafakân Adlı Kitap. Uluslararası Sosyal Araştırmalar Dergisi, 4(17), 48-62.

2. Aydın, E. (2011). Eski Türk Yazıtlarındaki Çıntan Igaç 'Sandal ağacı' Üzerine. Bilig, 56, 25-32.

3. Gözlü Kaya, E. (2012). "Eski Anadolu Türkçesiyle Yazılmış Tıp Metinlerindeki İki Terim Üzerine Tespitler: Çignemek ve Çeynemek”. Türk Dünyası Sosyal Bilimler Dergisi, 6o, 155-168.

4. Önler, Z. (1990). "Yağdığına İnanılan Bir Tür Kudret Helvası: Gezo". Frrat Üniversitesi Dergisi (Sosyal Bilimler), Elazı̆̆, C.4, S. 2., s.205-207.

5. Sevgi, E.- Kızılarslan, Ç. (2013). Bir İsim Çok Bitki - Mayasıl Otu. Avrasya Terim Dergisi, 1(1), 17-29.

Yukarıda açılamasını yaptığımız üzere tıp terimi olarak da kullanılan bitki adları üzerinde yoğunlaşan çalışmalar oldukça fazladır. Aşağıda vermiş olduğumuz çalışmalar da doğrudan tıbbi bitkilerle ilgili olmamakla birlikte bitkilerin adlandırılmaları üzerine yapılan çalışmalara örnek olarak verilebilir:

1. Alkayış, M. F. (2009). Türkçede Kullanılan Alıntı Bitki Adları. Turkish Studies International Periodical For the Languages, Literature and History of Turkish or Turkic, 4(4), 71-92.

2. Aydın M. (2008). Ordu ve Yöresi Ağızlarında Armut Adları. Turkish Studies International Periodical For the Languages, Literature and History of Turkish or Turkic, 3(3), 129-138.

3. Bläsing, U. (2004). Armut Sözcügünün Etimolojisi ve Yayılışına Dair Bazı Notlar. V. Uluslararası Türk Dili Kurultayı Bildirileri, Ankara, TDK, 473-485.

4. Doğan, N. (2011). Vezirköprü ve Havza Ağızlarında Yabani Bitki Adları. Diyalektolog, 2, 7-13.

5. Duran, A. (1998). Türkçede Bazı Bitki Adlarının Veriliş Sebepleri. Türk Dili, 555, 223-229. 
6. Erdal, M. (1993). Around the Turkic 'Apple'. The Journal of Indo-European Studies, 21(1-2), 2736.

7. Eren, H. (1999). “Ayva”. Türk Dili, 573, 739-748.

8. Hauenschild, I. (1999). Yarpuz-Anmerkungen zu Einem 'Ghostword'. UAJbN.F., 16, 202-210.

9. Kartalcık, V. (2008). Anadolu Ağızlarında Üzüm Adlandırmaları. Turkish Studies International Periodical For the Languages, Literature and History of Turkish or Turkic, 3(5), 663-711.

10. Magdolna, M. (2002). Tatár: A Eurasian Etymology: Sarmysak <*K’irmus(v) /Kermus(v) / Karmus(v) 'garlic'. $A O H, 55(1-3), 237-251$.

11. Özmen, M. (2010). Hatay-Erzin Başlamış Köyünden Derlenen Bitki Adları. Erdem, 58, 255-268.

12. Raschmann, S.C. (2010). Herbst-Baumwolle (küzki käpäz). Trans- Turkic Studies, 103-116.

13. Sertkaya, O. F. (2012). Adana, Begrek > Beyrek ve Elma Kelimelerinin Kökeni Üzerine. Türkoloji Dergisi, 19(2), 101-113.

14. Sertkaya, O. F. (2014). Elma Kelimesinin Kökeni Üzerine. Türk Dili, 75o, 63-66.

15. Stachowski, M. (1994). Türkisch sarymsak sarmysak 'Knoblauch'. TDİA, 4, 171-172.

16. Şen, M. (2006). "Elma” Kelimesi Üzerine. Büyük Türk Dili Kurultayı Bildirileri, Ankara: Bilkent Üniversitesi, $571-586$.

17. Şirin, H. (2010). Türk Dillerinde çilek ve yilek. Studies on the Turkic World, 131-138.

18. Uçar, İ. (2012). Türkiye Türkçesinde Hayvan Adlarından Türetilmiş Bitki Adları. TEKE, 2(1), 1-19.

19. Uçar, İ. (2013). Yetiştiği/Geldiği Coğrafya Veya Etnik Adlandırmayla Oluşturulan Bitki Adları. Zeitschrift für die Welt der Türken Journal of World of Turks, 5(1), 115-135.

20. Yavuz, M. (2016). Bazı Liken Cins (Genus) İsimlerinin Etimolojisi Üzerine. Avrasya Terim Dergisi, $4(2), 18-26$.

21. Yılmaz Y., Dağtaş H. (2014). Türkiye Türkçesinde Bitki Adları ve Yetiştiği Yerle İlişkisi. Akademik Sosyal Araştırmalar Dergisi, 2(6), 231-239.

\section{Tıp terimlerinin oluşturulması ve kullanımlarıyla ilgili çalışmalar}

Tıp terimlerinin günümüz Türkiye Türkçesinde kullanımlarıyla ilgili yapılan çalışmalar da mevcuttur. $\mathrm{Bu}$ çalışmalar daha çok tıp terimleriyle kurulan deyimler veya bir ağız merkezli sağlık deyişleriyle ilgili çalışmalardır. Bunlar dışında hastalık ve tıbbi bitki adlarını oluşumları bakımından inceleyen çalışmalar da mevcuttur.

1. Gülseren, C. (2001). Halk Dilinde Uşak’ta Bitki Adları ve Sağlı Deyişleri. Afyon Kocatepe Ü. Sosyal Bilimler Dergisi, 3(2), 107-117. 
2. Koç, A. (2010). Hastalık İsimlerinde Örtmece. Türk Dünyası Araştırmaları, 188, 77-94.

3. Tokat, F. (2014). Türkçede Tıp Terimleri İle Kurulmuş Deyimler. Avrasya Terim Dergisi, 2(2), 11-19.

4. Uçar, İ. (2012). Türkiye Türkçesinde Organ Adlarıyla Oluşturulmuş Bitki Adları. Türklük Bilimi Araştırmaları, 17, 285-306.

5. Uçar, İ. (2010). Türkçede Eş Anlamlılık ve Eski Anadolu Türkçesi Tıp Yazmalarında Eş Anlamlı Kelime Kullanımı. Zeitschrift für die Welt der Türken/Journal of World of Turks, 21, 37-48.

\section{Tıp terimleri sözlükleri ile ilgili yapılan çalışmalar}

Bibliyografyamızın son bölümü ise terimler için en önemli kaynak olan sözlüklerle ilgili yapılan çalışmalardan oluşmaktadır. Tıp-sağlık terimlerini anlamlandırmamıza yardımcı olan sözlük çalışmaları hakkında bilgi edinmemizi sağlayan önemli bir çalışma Şaban Doğan’ın “XV.-XVIII. Yüzyıllar Arasında Anadolu Sahasında Türkçe Yazılmış Tıp ve Eczacılık Sözlükleri” adlı bildirisidir. Bu çalışma sayesinde tıp yazmalarıyla ilgili çalışma yapan araştırmacılara tıp terimlerini anlamlandırmada yararlanacakları birçok tıp-ecza sözlüğü hakkında bilgi verilmektedir.

Tıp sözlükleri hakkında bazı lisansüstü tez çalışmaları da mevcuttur. Burada bahsettiğimiz çalışmalar herhangi bir tıp metninin sonunda verilen dizin-sözlük çalışmalarını değil, sadece tıp terimlerini konu alan sözlük çalışmalarını kapsamaktadır. Konuyla ilgili birçok sözlük yayımlanmıştır. Bizim burada verdiğimiz çalışmalar ise sadece tıp terimleriyle ilgili olan yayımlanmamış lisansüstü tezler ile tıp terimlerini konu alan sözlük çalışmalarıdır:

1. Akkuş, M. (2008). Siyahî Karamanî Larendevî'nin Mecmâ'-i Tip Adlı Eseri (Gramer-Metin-Sözlük). (Basılmamış yüksek lisans tezi). Erciyes Üniversitesi/Sosyal Bilimler Enstitüsü, Kayseri.

2. Murad, S. (2009). Lügât-ı Müşkilât-ı Eczâ Derviş Siyâhhî Lârendevî (Giriş-Metin-İnceleme-Dizin). (Basılmamış yüksek lisans tezi). Sakarya Üniversitesi/Sosyal Bilimler Enstitüsü, Sakarya.

3. Demir, E. (2011). Hezârfen Hüseyin b. Ca'fer İstânköyî'nin Lisânü'l-Etibbâ Adlı Tip Lügati Üzerinde Dil İncelemesi: İnceleme-Metin-Sözlük. (Basılmamış doktora tezi). İstanbul Üniversitesi/Sosyal Bilimler Enstitüsü, İstanbul.

Lisansüstü çalışmalar dışında tıp terimleri sözlükleriyle ilgili en kapsamlı çalışmalar Şaban Doğan’a ait olup bu çalışmalar aşağıda verilmiştir. Bunlara ek olarak tarafımızca müellifi belli olmayan bir tıp sözlüğünün metni yayımlanmıştır:

1. Doğan, Ş. (2009). 15. Yüzyıla Ait Bir Tip Terimleri Sözlüŭü: Terceme-i Akrabâdîn"in Istılah Lügati, Turkish Studies International Periodical For the Languages, Literature and History of Turkish or Turkic, 4(4), 250-316.

2. Doğan, Ş. (2010). XV.-XVIII. Yüzyıllar Arasında Anadolu Sahasında Türkçe Yazılmış Tıp ve Eczacılık Sözlükleri. IV. Uluslararası Dünya Dili Türk Sempozyumu Bildiri Kitabı, C. II, Muğla, Aralık 2011, $103-114$ 
3. Doğan, Ş. (2011). On Yedinci Yüzyılda Kaleme Alınmış Bir Tıp ve Eczacılık Sözlügü̈: Lügât-ı Müşkilât1 Eczâ. Osmanlı Bilimi Araştırmaları, 95-104.

4. Murad, S. (2018). Müellifi Bilinmeyen Bir Tıp Sözlüğü. RumeliDe Dil ve Edebiyat Araştırmaları Dergisi,12 (Ekim), 35-67.

Doğrudan tıp-ecza alanlarıyla ilgili olmasa da birçoğu tıbbi bitkilerden oluştuğu için çalışmamızın bu kısmında yer vereceğimiz bir çalışma da Hatice Şahin'e (2007) ait “Cami'ü’l-Fürs Örneğinde XVI. Yüzyll Bitki İsimleri” adlı çalışmadır. Bu çalışmada, 1501-1502 tarihinde Türklere Farsçayı öğretmek amacıyla mensur bir sözlük olarak yazılmış Cami‘ü'l-Fürs'teki sekiz bin Farsça isim maddesi içinde bulunan Arapça, Farsça, Türkçe, Grekçe bitki adları ve anlamları verilmiştir:

1. Şahin, H. (2007). Cami'ü’l-Fürs Örneğinde XVI. Yüzyll Bitki İsimleri. Turkish Studies International Periodical For the Languages, Literature and History of Turkish or Turkic, 2(2), 570-602.

\section{Sonuç}

Bibliyografya denememize dâhil ettiğimiz 1’i yabancı araştırmacılara ait toplam 88 çalışma bulunmaktadır. Bunlardan "tıp terimleri” başlıklı 21 adet çalışmanın 3’ü Dîvânu Lugâti't-Türk ve Kutadgu Bilig, 1’i Eski Uygur Türkçesi tıp metinleri üzerinedir. 16 çalışma Eski Anadolu ve Osmanlı Türkçesi dönemi ve eserleri, 1 adet çalışma da Karakalpak Türkçesi tıp terimleriyle ilgilidir.

Tıp terimleri içine giren tıpta kullanılan ilaç, bitki, hayvansal madde, hastalık, tıbbi alet vb. adları üzerine yapılan çalışmalardan 28 tanesi Eski, Karahanlı, Eski Anadolu ve Osmanlı Türkçesi dönemlerine ait doğrudan ya da dolaylı olarak tıpla ilgili eserlerde yer alan tıbbi terimler üzerine olup, 20 tanesi tıbbi bitkilerle ilgilidir. Diğer 8 çalışma ise hayvansal droglar, hastalık adları, tıbbi alet adları ve tıp fiilleriyle ilgili yapılmış çalışmalardır.

Tek bir terim üzerinde duran çalışmaların çoğu yine tıbbi bitki adlarıyla ilgilidir. Bu çalışmalarda bitki adının etimolojisi üzerinde durulmuştur. Bazı çalışmalar da tıp metinlerinde geçen bir sözcük hakkındaki bilgileri içermektedir. Bu bölümde de 26 çalışma mevcuttur.

Tıp terimlerinin oluşturulması ve kullanımlarıyla ilgili çalışmalar bölümünde ise bitki-hastalık adlarının oluşum şekilleri hakkında ve halk arasında kullanılan tıpla ilgili deyişler üzerine de yapılan çalışmalar toplam 5 adettir.

Tıp metinleri hakkında çalışma yapanlar için önemli bir kaynak olan tıp terimleri sözlükleri hakkında 2 yüksek lisans, 1 doktora tezi olmak üzere 8 adet çalışma tespit edilmiştir. Bu çalışmaların diğger beşi ise tıp terimleri sözlüklerini tanıtan makalelerden oluşmaktadır.

Yine bu bölüme dâhil edebileceğimiz Farsça-Türkçe sözlükte geçen tıbbi bitki adlarıyla ilgili bir çalışma da bulunmaktadır.

Tıp terimleri üzerine yapılan çalışmalar hakkındaki bibliyografya denememizde, tıp terimleri sahasında çalışanlara fayda sağlayacak birçok çalışmanın yapıldığı görülmüştür. Bununla birlikte tıp metinlerinde kullanılan fiiller hakkında çok fazla çalışmanın yapılmamış olduğunu söyleyebiliriz. Çalışmaların çoğu bitki, hayvan, ilaç ve hastalık adlarıyla ilgilidir. Tıp metinlerinde en çok karşılaşılan durumlardan biri 
de bir bitkiye verilen farklı ve alakasız adlandırmalardır. Bu konu hakkında yapılan çalışmalar da az sayıdadır.

$\mathrm{Bu}$ bibliyografya denememizin, hem tarihî tıp metinleri üzerine çalışma yapacak araştırmacılara çalışılmayan konular hakkında fikir vermesi hem de kullanılacak kaynaklar hakkında fayda sağlaması temennisindeyiz.

\section{Kaynakça}

Baytop, T. (1984). Türkiye'de Bitkilerle Tedavi; Geçmişte ve Bugün. İstanbul: Nobel Tıp Kitabevleri.

Canpolat M., Önler Z. (2007). İshâk bin Murâd, Edviye-i Müfrede. Ankara: TDK Yayınları.

Derin A. (1987). Tuhfe-i Mübârizî (Metin-Gramer Notlart-Sözlük). (Basılmamış yüksek lisans tezi), Gazi Üniversitesi/Sosyal Bilimler Enstitüsü, Ankara.

Erdağı B. (2001). Tuhfe-i Mübârizî (İnceleme-Metin-Sözlük). (Basılmamış doktora tezi), Hacettepe Üniversitesi/Sosyal Bilimler Enstitüsü, Ankara.

Koman, M. M. (1955). Tuhfe-i Mübârizî (Lübab-ün Nuhab Tercümesi), İ.Ü. Tip Fakültesi Mecmuası, 18(13), 689-719.

Murad, S. (2009). Lügât-ı Müşkilât-ı Eczâ Derviş Siyâhî Lârendevî (Giriş-Metin-İnceleme-Dizin). (Basılmamış yüksek lisans tezi), Sakarya Üniversitesi/Sosyal Bilimler Enstitüsü, Sakarya.

Önler, Z. (1990). Müntehâb-ı Şifâ I. Ankara: Türk Dil Kurumu Yayınları. 